\title{
PARTIAL LAPAROSCOPIC ADRENALECTOMY FOR ALDOSTERONOMA: OUR EXPERIENCE
}

\author{
ZVONIMIR MISIR, GORAN GLAVČIĆ, SUZANA JANKOVIĆ and JAKŠA FILIPOVIĆ-ČUGURA \\ Department of Upper Gastrointestinal Surgery, Sestre milosrdnice University Hospital Center, \\ Zagreb, Croatia
}

\begin{abstract}
Summary
Background: Since its first description in 1992, laparoscopic adrenalectomy has become the gold standard for the surgical treatment of most adrenal conditions. We demonstrated the safety and feasibility of the laparoscopic technique in patients with primary hyperaldosteronism caused by solitary aldosteronoma treated by laparoscopic partial adrenalectomy.

Aim: To demonstrate safety and feasibility of laparoscopic partial adrenalectomy in aldosterone-producing adenomas.

Materials and methods: From 1992. to the present time, 13 patients presented with hyperaldosteronism and a single adrenal adenoma (Conn's syndrome) and were treated with laparoscopic partial adrenalectomy. The mean age was 65 years, and the average tumor size was $1.35 \mathrm{~cm}$ in diameter. The mean follow-up of our patients for hypertension and local reccurence was 36 months (range 6-72 months). A transperitoneal approach was used in all patients, tumors were resected with safety margins by ultrasonic device.

Results: All procedures were finished laparoscopically, and no conversion was necessary. The mean duration of the operations was 65 minutes, with a mean bleeding rate of $40 \mathrm{ml}$. No major intraoperative or postoperative complication was observed. Postoperative mean hospital stay was 4 days. In all the cases, hypertension improved totally or partially, and no local recurrence was observed.

Conclusion: Laparoscopic partial adrenalectomy for aldosterone-producing adenomas is a minimally invasive procedure with a low complication rate. This procedure can be performed with good results for patients with small aldosteronomas of the adrenal gland, even with a healthy contralateral adrenal gland.
\end{abstract}

KEYWORDS: primary aldosteronism; laparoscopy; partial adrenalectomy

\section{INTRODUCTION}

Since its introduction in 1992. laparoscopic adrenalectomy has become the gold standard operation for the treatment of benign adrenal gland tumors(1). Previous studies have demonstrated that laparoscopic adrenalectomy is curative and can be performed safely for primary aldosteronism with all the advantages of minimally invasive

Corresponding author: Zvonimir Misir, Department of Upper Gastrointestinal Surgery, Sestre milosrdnice University Hospital Center, Vinogradska cesta 29, 10000 Zagreb, Croatia. E-mail: zvonimir.misir@kbcsm.hr surgery $(2,3)$. Unilateral adrenalectomy performed for single side lesions leaves patients with enough hormonal reserve(4). The presence of healthy contralateral gland does not justify the complete removal of the diseased gland. A small risk of losing the second adrenal gland later on, would require lifelong steroid replacement therapy. Therefore, leaving as much functional adrenal tissue as possible provides these patients with more functional reserve(5). We present our initial experience with partial laparoscopic adrenalectomy for solitary aldosterone secreting adrenal adenomas. 


\section{PATIENTS AND METHODS}

From 1992 to the present time, 68 patients were treated with laparoscopic approach for various adrenal gland diseases in the Department of Surgery at Clinical Hospital Centre Sestre milosrdnice. In 13 selected patients with primary hyperaldosteronism caused by a small, single aldosterone-producing adenoma, and normal contralateral gland, we performed partial adrenalectomy. All patients were referred to us for laparoscopic treatment from different endocrine departments, where the diagnosis was assessed by determining the adrenal hormones in serum and urine and by the determination of serum electrolytes. All patients had elevated aldosterone levels, and their potassium was less than the normal range. In order to confirm the unilateral adrenal disease, venous sampling (AVS), CT scan, and MRI were performed in all patients preoperatively $(6,7)$. The average age of our 13 patients was 60 years (range 24 to 75); five were women and eight men. The tumor distribution was four on the right and nine on the left side. The average tumor size was $1.35 \mathrm{~cm}$ (range 1.1 to $1.9 \mathrm{~cm}$ ). The exclusion criteria for partial adrenalectomy were a diameter greater than 3 $\mathrm{cm}$ and tumors located in a relatively central position in the gland $(8,9)$. Using these criteria, one can expect a sufficient amount of functional tissue after the resection. The median follow-up of our patients was 36 months (range 6-72 months).

\section{SURGICAL TECHNIQUE}

For laparoscopic partial resection, we have always performed a transperitoneal approach, as described previously for transperitoneal adrenalectomy(10).

It is important to expose the whole gland and the tumor completely before beginning the partial resection. To preserve the blood supply of the remnant adrenal gland, mobilization of the tumor within benign margins should be started at the side of the tumor. Furthermore, the unaffected portion of the gland should not be dissected to preserve the blood supply of the remnant.

On the right side, the liver is mobilized and retracted first. The procedure is started with dissection of the peritoneum next to the inferior vena cava at the level of the right kidney hilum up to

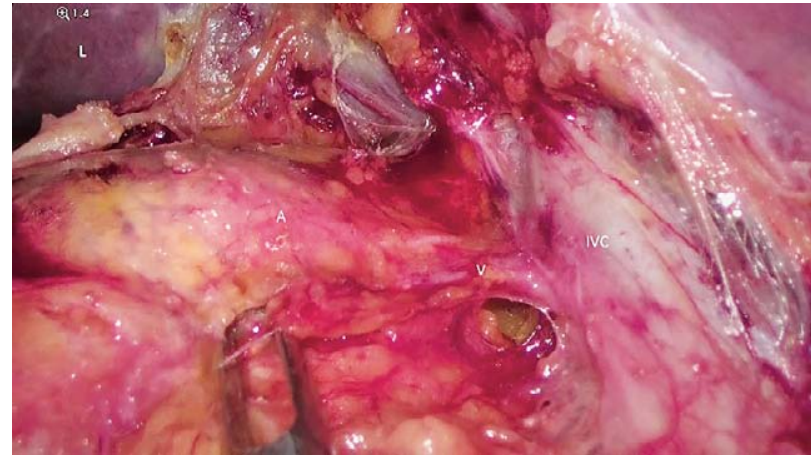

Figure 1 Intraoperative image od right laparoscopic adrenalectomy. $A$, adrenal gland; IVC, inferior vena cava; $V$, main adrenal vein; $L$, liver.

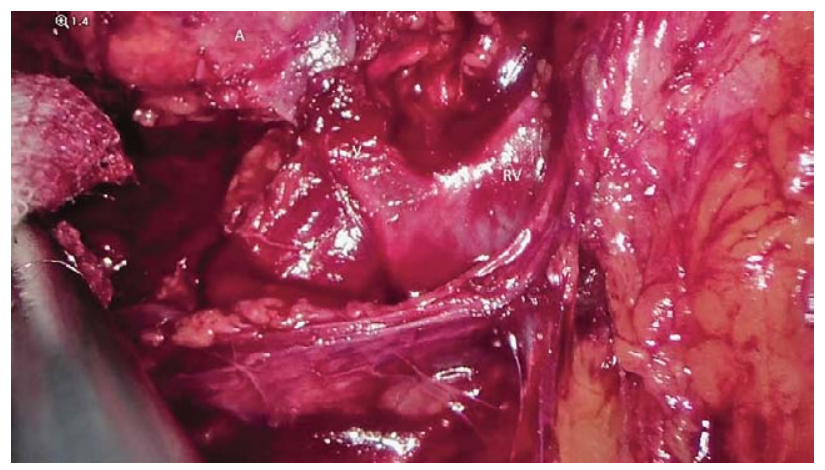

Figure 2 Intraoperative image of left laparoscopic adrenalecto$m y$. $A$, adrenal gland; $R V$, renal vein; $V$, main adrenal vein

the inferior border of the liver. This dissection was extended laterally and parallel to the liver up to the diaphragm (Figure 1).

For left adrenal tumors, the colonic flexure is mobilized and the splenorenal ligament dissected. The spleen and the tail of the pancreas were retracted medially for about $180^{\circ}$. This maneuver gave us complete exposure of the left adrenal area. After exposure of the adrenal gland, meticulous dissection of the tumor started. The central adrenal vein was kept intact, and the connective tissue around the normal adrenal gland was left undisturbed to preserve the blood supply (Figure 2).

The tumor resection itself was carried out with the harmonic device after verifying tumor location using laparoscopic ultrasound device. The resected tumor was put in an extraction bag. In all patients, a drain was left in place for 2 days. The tumor was then retrieved from the abdomen within the bag by slightly widening one of the trocar incisions. 


\section{RESULTS}

In all patients surgery was completed laparoscopically without any major postoperative complications. The estimated blood lost ranged from 10 to $100 \mathrm{~mL}$, and no patient needed blood transfusion. The mean operative time was 65 minutes (range 35 and 130). All the patients started oral intake within the first 24 hours after surgery. The postoperative hospital stay ranged from 3 to 6 days with a mean of 4 days. Five patients had normal blood pressure after surgery. In the other two patients, the blood pressure improved, but they still needed medications. All diagnoses were confirmed histopathologically.

The serum aldosterone levels returned to normal, and the blood pressure readings were in the age-related normal ranges at follow-up. In all patients, the serum potassium level climbed to greater than $4,2 \mathrm{mmol} / \mathrm{L}$ and all patients who required spironolactone or other antihypertensive drugs before surgery were able to refrain from this treatment. No local tumor recurrences were observed with a median follow-up of 36 months.

\section{DISCUSSION}

For a long time, unilateral total adrenalectomy has been considered the technique of choice in patients with surgically correctable primary aldosteronism. However, unilateral partial adrenalectomy has also been advocated to preserve the remnant adrenal function and avoid potential adrenal insufficiency(5). Walz suggested that aldosterone producing adenomas could be an ideal indication for partial adrenalectomy, because these tumors are almost always benign, small, and often lie eccentrically(11). Furthermore, other studies reported results of partial adrenal resections for aldosteronoma with no recurrent hyperaldosteronism and with a greater reserve of normal ipsilateral adrenal tissue and low complication rate $(12,13)$.

In our series, we used the transperitoneal approach in all patients. The instrument used for the dissection must not damage the healthy tissue of the gland to guarantee the vitality of the gland remnant. In our experience, we used the ultrasonic scalpel, which offers the advantage of a clean surgical field.

So far, none of our patients clinically developed adrenal insufficiency, nor did they develop any recurrence after partial adrenalectomy within 36 months' median follow-up. However, partial adrenalectomy will not be feasible if hyperaldosteronism is caused by nodular hyperplasia of the adrenal gland. Therefore, careful investigations employing modern imaging techniques are mandatory to identify the adenoma preoperatively clearly.

\section{CONCLUSION}

Laparoscopic partial adrenalectomy for aldosterone-producing adenomas is a safe and minimally invasive procedure with a low complication rate. The main advantage of partial adrenalectomy is retaining functional tissue on the side of the affected adrenal gland in case of subsequent adrenalectomy on the contralateral side for other reasons. Therefore, we recommend laparoscopic partial adrenalectomy for patients with primary aldosteronism who have small, peripheral adrenal gland tumors so that adequate remnant function can be expected.

\section{REFERENCES}

1. Suzuki K, Kageyama S, Ueda D, Ushiyama T, Kawabe K, Tajima A, i sur. Laparoscopic adrenalectomy: clinical experience with 12 cases. J Urol. 1993;150(4):1099-102.

2. Kulis T, Knezevic N, Pekez M, Kastelan D, Grkovic M, Kastelan Z. Laparoscopic adrenalectomy: lessons learned from 306 cases. J Laparoendosc Adv Surg Tech A. 2012;22(1):22-6.

3. Shen WT. Laparoscopic vs Open Adrenalectomy for the Treatment of Primary Hyperaldosteronism. Arch Surg. 1999;134(6):628.

4. Nakada T, Kubota Y, Sasagawa I, Yagisawa T, Watanabe $\mathrm{M}$, Ishigooka $\mathrm{M}$. Therapeutic outcome of primary aldosteronism: adrenalectomy versus enucleation of aldosterone-producing adenoma. J Urol. 1995;153 (6):1775-80.

5. Fu B, Zhang X, Wang G, Lang B, Ma X, Li H, i sur. Long-term results of a prospective, randomized trial comparing retroperitoneoscopic partial versus total adrenalectomy for aldosterone producing adenoma. J Urol. 2011;185(5):1578-82.

6. Young WF, Stanson AW, Thompson GB, Grant CS, Farley DR, van Heerden JA. Role for adrenal venous sampling in primary aldosteronism. Surgery. 2004; 136(6):1227-35.

7. Magill SB, Raff H, Shaker JL, Brickner RC, Knechtges TE, Kehoe ME, i sur. Comparison of adrenal vein sampling and computed tomography in the differentia- 
tion of primary aldosteronism. J Clin Endocrinol Metab. 2001;86(3):1066-71.

8. Roukounakis N, Dimas S, Kafetzis I, Bethanis S, Gatsulis $\mathrm{N}$, Kostas $\mathrm{H}$, i sur. Is preservation of the adrenal vein mandatory in laparoscopic adrenal-sparing surgery? JSLS J Soc Laparoendosc Surg. 2007;11(2): 215-8.

9. Imai T, Tanaka Y, Kikumori T, Ohiwa M, Matsuura N, Mase T, i sur. Laparoscopic partial adrenalectomy. Surg Endosc. 1999;13(4):343-5.

10. Miron A, Giulea C, Nădrăgea M, Enciu O. Laparoscopic Partial Adrenalectomy. Chirurgia (Bucur). 2017;112(1):77-81.
11. MK W. Extent of adrenalectomy for adrenal neoplasm: cortical sparing (subtotal) versus total adrenalectomy. Surg Clin North Am. 2004;84(3):743-53.

12. Jeschke K, Janetschek G, Peschel R, Schellander L, Bartsch G, Henning K. Laparoscopic partial adrenalectomy in patients with aldosterone-producing adenomas: Indications, technique, and results. Urology. 2003;61(1):69-72.

13. Nakada T, Kubota Y, Sasagawa I, Yagisawa T, Watanabe M, Ishigooka M. Therapeutic Outcome of Primary Aldosteronism: Adrenalectomy Versus Enucleation of Aldosterone-Producing Adenoma. J Urol. 1995;153(6):1775-80.

\section{Sažetak \\ DJELOMIČNA LAPAROSKOPSKA ADRENALEKTOMIJA KOD ALDOSTERONOMA: NAŠE ISKUSTVO}

\section{Z. Misir, G. Glavčić, S. Janković, J. Filipović-Čugura}

Uvod: Od kada je po prvi puta opisana, laparoskopska adrenalektomija postala je zlatni standard u liječenju većine tumora nadbubrežne žlijezde. Pokazali smo sigurnost laparoskopskog pristupa kod bolesnika s primarnim hiperaldosteronizmom uzrokovanog solitarnim aldosteronomom liječenih djelomičnom adrenalektomijom.

Cilj: Pokazati sigurnost i izvedivost laparoskopske djelomične adrenalektomije kod adenoma koji luče aldosteron.

Materijali i metode: Od 1992. godine do danas, 13 bolesnika s primarnim hiperaldosteronizmom uzrokovanim solitarnim adenomom nadbubrežne žlijezde bilo je liječeno djelomičnom laparoskopskom adrenalektomijom. Prosječna dob bolesnika bila je 65 godina i veličina tumora 1,35 cm u promjeru. Pacijenti su praćeni kroz prosječno razdoblje od 36 mjeseci (raspon od 6-72 mjeseca). Kod svih bolesnika korišten je transperitonealni pristup pri čemu je za resekciju tumora korišten ultrazvučni nož.

Rezultati: Svi operacijski postupci završeni su laparoskopski, bez potrebe za konverzijom. Prosječno trajanje operacijskog zahvata bilo je 65 minuta, s prosječnim gubitkom krvi od oko $40 \mathrm{ml}$. Nije bilo većih intraoperativnih ili postoperativnih komplikacija. Prosječno trajanje hospitalizacije bilo je 4 dana. Kod svih bolesnika postoperativno je došlo do potpune ili djelomične korekcije hipertenzije bez pojave lokalnog recidiva.

Zaključak: Laparoskopska djelomična adrenalektomija kod aldosteronoma je minimalno invazivna procedura s malom pojavnošću komplikacija. Proceduru je moguće izvesti s dobrim rezultatima kod bolesnika s malim aldosteronomima nabubrežne žlijezde čak i slučajevima zdrave kontralateralne žlijezde.

KLJUČNE RIJEČI: primarni aldosteronizam; laparoskopija; djelomična adrenalektomija 